STEFAN T. KWIATKOWSKI

Chrześcijańska Akademia Teologiczna

$w$ Warszawie

INETTA NowOSAD

Uniwersytet Zielonogórski

\title{
SYSTEM KSZTAŁCENIA I DOSKONALENIA NAUCZYCIELI W SINGAPURZE. MIĘDZY UTOPIJNĄ WIZJĄ A RZECZYWISTOŚCIĄ
}

\begin{abstract}
AвSTRACт. Kwiatkowski Stefan T., Nowosad Inetta, System ksztatcenia i doskonalenia nauczycieli w Singapurze. Między utopijna wizją a rzeczywistościa [Teacher Education and Professional Development System in Singapore. Between Utopian Vision and Reality]. Studia Edukacyjne nr 47, 2018, Poznań 2018, pp. 147-171. Adam Mickiewicz University Press. ISSN 1233-6688. DOI: 10.14746/se.2018.47.10

Starting from the concept of utopia, the article focuses itself on the analysis of teacher education and professional development system that has evolved in Singapore over the last few decades. On the wider background of this particular model's elements, a description of the institutions responsible for teacher continuing education, established to prepare them to the fundamental task they are meant to perform in the modern knowledge society, has been provided.
\end{abstract}

Key words: teacher, Singapore, education, continuing education, professional development

\section{Wprowadzenie}

W dziejach ludzkości utopie wyrażały tęsknotę człowieka za lepszym światem. Bez wątpienia, były świadectwem przyjmowania idei postępu wyłaniając się ze zbiorowych nadziei artykułowanych przez wybitne jednostki. Stanowiły wizję przyszłości powstałą przez odrzucenie stanu zastanego. Zdaniem Jerzego Szackiego, utopia „rodzi się wtedy, gdy w świadomości ludzkiej zjawia się rozdarcie między światem, który jest, a światem, który jest do pomyślenia"1. Utopie dla jednych stanowiły marzenie, nieosiągalne

\footnotetext{
${ }^{1}$ J. Szacki, Spotkania z utopia, Warszawa 1980, s. 28.
} 
pragnienie, by w późniejszym czasie dla innych być już pokusą sprzyjającą twórczym dążeniom. $W$ takim rozumieniu utopie przyspieszały procesy adaptacyjne człowieka w szeroko pojętym środowisku naturalnym i kulturowym, odrzucając zastany porządek na rzecz radykalnych, dogłębnych zmian w imię lepszego jutra.

Utopie na stałe wpisały się $\mathrm{w}$ mechanizm rozwoju społeczeństwa mobilizując działania zarówno jednostek, jak i zbiorowości do podejmowania decyzji na rzecz zmiany ludzkiej egzystencji². W efekcie stanowią budulec wielu dążeń ukierunkowanych na przebudowę świata. Również dzisiejsze rozwiązania stanowią pochodną czyjegoś pomysłu, często niemożliwego do zrealizowania w realiach danej epoki. Jednak, w dziejach ludzkości utopie społeczne były także oskarżane o sianie nienawiści i wywoływanie wojen ${ }^{3}$. Zwrócono uwagę, iż literackie utopie od chwili wdrożenia ich w życie zaczęły się zmieniać $w$ posiadające negatywny oddźwięk ideologie, niebezpieczne dla społeczeństwa, które je ukształtowało 4 .

Bez względu na skutki, podejście utopijne wciąż pozostaje aktualne i dla wielu inspirujące. Nie jest jednak zamierzeniem autorów opracowania zgłębianie fenomenu utopii, lecz zwrócenie uwagi na istniejący w Singapurze system kształcenia i doskonalenia nauczycieli, który można przez ten pryzmat rozpatrywać. Wszelkie działania edukacyjne, w tym skuteczność teorii pedagogicznych, czy też koncepcji szkolnictwa, jak i nowych rozwiązań można analizować przez pryzmat utopii, bowiem ich praktyczna wartość wymierna w efektach edukacyjnych widoczna jest dopiero w przyszłości. Jest zawsze efektem czyjejś wizji i realizacji określonej idei.

Istnieje wiele strukturalnych powiązań utopii i pedagogiki. Gdyby się pozbawiło pedagogikę pierwiastka utopijnego, wtedy każda jej teoria, każda systemowa koncepcja szkolnictwa straciłaby sens istnienia ${ }^{5}$.

Podejmując się analizy systemu kształcenia i doskonalenia nauczycieli w Singapurze, trudno jednak odwoływać się do Platońskiej wizji „złotych mędrców" na szczycie państwa/miasta, lecz bardziej do utopii wolnego rynku, która "znajduje się w fazie systematycznej progresji - jako mocniej ufundowana i nowocześniejsza, bardziej amoralna i bardziej wyzuta z ograniczeń niż wszelkie dotychczasowe utopie" ${ }^{\prime \prime}$. W sferze edukacji jest przykładem wysoce efektywnego systemu zorientowanego na wysoką jakość procesów edu-

${ }^{2}$ R. Włodarczyk, Utopia w perspektywie pedagogiki wspótczesnej, [w:] Utopia a edukacja, red. J. Gromisz, R. Włodarczyk, t. 1 - O wyobrażeniach świata możliwego, Wrocław 2016, s. 67-87.

${ }^{3}$ A. Drożdż, Mity i utopie pedagogiczne, Kraków 2000, s. 55.

${ }^{4}$ Por. komunizm lub narodowy socjalizm.

${ }^{5}$ A. Drożdż, Mity i utopie pedagogiczne, s. 8; J. Szacki, Spotkania z utopia.

${ }^{6} \mathrm{M}$. Gałażewski, Atopia w teorii systemów autopojetycznych, [w:] Utopia a edukacja, s. 44. 
kacyjnych opracowanych przez wspólnotę praktyków, naukowców, polityków oraz biznesmenów realizujących z laserową precyzją nowe idee biznesu w kulturze instant ${ }^{7}$. Jego

protagonistami nie są fantaści społeczni, płomienni rewolucjoniści, lecz chłodno kalkulujące, bezosobowe instytucje, jak Bank Światowy czy Międzynarodowy Fundusz Walutowy, amerykański FED, finansiści i maklerzy z Wall Street, transnarodowe koncerny, trusty i holdingi, globalne fundusze inwestycyjne. Utopia uniwersalnego wolnego rynku radykalne znosi granice między państwami czy kontynentami i czyni „niewidzialną rękę rynku” Adama Smitha dźwignią globalnej transformacji, która dobrobyt narodów i dobrostan udziałowców [shareholder] podnosi do rangi globalnej szczęśliwości [pursuit of hapiness] ${ }^{8}$.

Transformacji ulega tu przede wszystkim pojęcie wiedzy, co w konsekwencji prowadzi do zmiany praktycznego jej znaczenia jako zasobu funkcjonalnego społeczeństwa ${ }^{9}$. $Z$ tej perspektywy prezentowane $w$ tekście rozważania, osadzone $\mathrm{w}$ warunkach ekonomicznego porządku świata, mogą stanowić wyzwanie dla myślenia i działania wszystkich zainteresowanych jakością edukacji, potencjałem badań naukowych i doświadczaniem praktyki społecznej - mogą budzić niepokój, zastanawiać, ale także swoją precyzją i skutecznością uwodzić.

\section{Singapur - niekwestionowany lider}

Singapur jest obecnie uznawany za swego rodzaju "państwo wzorcowe” zarówno jeśli chodzi o budzącą podziw innowacyjność oraz wysoce wykwalifikowaną kadrę nauczycielską i niezwykle efektywne szkoły, jak i ze względu na jeden z najwyższych w skali światowej wskaźnik wzrostu gospodarczego - PKB na osobę oraz stale wzrastającą konkurencyjność w sferze globalnej gospodarki (co niewątpliwie nie pozostaje bez związku nie tylko z szeroko pojętą innowacyjnością, ale także z ponadprzeciętną jakością kształcenia - PKB stanowi bowiem, w dużym skrócie, pośrednią wypadkową obu tychże czynników $)^{10}$. Od połowy lat dziewięćdziesiątych XX wieku Singapur rozpoczął starania o pozycję znaczącego gracza w globalnej gospodarce opartej na wiedzy, promując rozwój przemysłu opartego na badaniach i innowacjach po-

${ }^{7}$ Pojęcie kultury instant za: Z. Melosik, Kultura instant. Paradoksy post-tożsamości, [w:] Edukacja. Społeczne konstruowanie idei i rzeczywistości, red. M. Cylkowska-Nowak, Poznań 2000, s. 372-385.

${ }^{8}$ Por. M. Gałażewski, Atopia w teorii systemów, s. 43.

9 Tamże, s. 52.

${ }^{10}$ World Economic Forum, The Global Competitiveness Report 2014-2015: Country/Economy Highlights, New York 2014, s. 2. 
przez przyciąganie naukowców i firm z całego świata. Wyniki takiej polityki gospodarczej rządu przerosły najśmielsze oczekiwania. Nastąpił gwałtowny wzrost gospodarczy, który wyniósł Singapur do grona liderów wśród państw wysoko rozwiniętych.

Przekształciwszy się z rozwijającego się kraju w nowoczesną gospodarkę przemysłową na przestrzeni życia jednego pokolenia, Singapur uosabia jedną z azjatyckich historii sukcesu ${ }^{11}$. Głównym źródłem konkurencyjności Singapuru jest umiejętność skutecznego dopasowania podaży do potrzeb. Innymi elementami sukcesu są: klarowna wizja oraz wiara w kluczowe znaczenie wykształcenia, zarówno dla uczniów jak i dla narodu; wytrwałe przywództwo polityczne oraz koordynacja teorii z praktyką; skupienie na budowaniu potencjału nauczycielskiego i zdolności przywódczych do przeprowadzania reform na poszczególnych szczeblach edukacji; ambitne standardy i systemy oceniania; a także kultura ciągłego doskonalenia i orientacji na przyszłość widzianej jako konkurująca $\mathrm{z}$ najlepszymi praktykami edukacyjnymi na świecie. Włożony wysiłek udowodnił, że najważniejszym zasobem stanowiącym o sukcesie kraju są jego obywatele.

W ciągu ostatniej dekady system edukacji w Singapurze konsekwentnie sytuował się na szczycie większości najważniejszych światowych rankingów edukacyjnych ${ }^{12}$. Osiągnięcia uzyskiwane przez singapurskich uczniów są jednym z najważniejszych wyznaczników jakości i efektywności instytucji edukacyjnych. Przykładem są między innymi wyniki przeprowadzanych w trzyletnich odstępach badań PISA (Programme for International Student Assessment - Program Międzynarodowej Oceny Umiejętności Uczniów) nadzorowanych przez OECD (Organizację Współpracy Gospodarczej i Rozwoju), uwzględniających wyniki uzyskiwane przez 15-letnich uczniów w trzech kluczowych obszarach: umiejętności czytania i interpretacji tekstu (reading literacy), umiejętności matematycznych (mathematical literacy) oraz rozumowania w naukach przyrodniczych (scientific literacy) ${ }^{13}$. Rezultaty uzyskane w badaniu PISA przez singapurskich uczestników edycji z 2015 roku muszą budzić podziw - w każdej z branych pod uwagę w badaniu dziedzin są najlepsi i lo-

11 W dobie uzyskania przez Singapur niepodległości w 1959 r., większość spośród dwóch milionów ówczesnych jego obywateli stanowiły osoby niepiśmienne i/lub niewykwalifikowane, co było pokłosiem obowiązującego w erze kolonialnej (przed uzyskaniem niepodległości Singapur wchodził w skład Imperium Brytyjskiego) systemu edukacji, dedykowanego przede wszystkim zamożniejszej, stanowiącej mniejszość społeczeństwa, za: OECD, Lessons from PISA for the United States, s. 161.

12 E.-L. Low, O.-S. Tan, Teacher Education Policy: Recruitment, Preparation and Progression, [w:] Teacher Education in the 21st Century. Singapore's Evolution and Innovation, red. O.-S. Tan, W.-C. Liu, E.-L. Low, Singapore 2017, s. 12.

13 OECD, PISA 2012 Results in Focus. What 15-year-olds know and what they can do with what they know, Paris 2014, s. 4-7. 
kują się na pierwszym miejscu światowej czołówki, wyraźnie dystansując pozostałe kraje $\mathrm{e}^{14}$. Warto dodać, że singapurscy uczniowie po raz pierwszy wzięli udział w badaniu PISA dopiero w 2009 roku, czyli w czwartej już edycji, jednak i wcześniej osiągali bardzo wysokie wyniki w innych uznanych, prestiżowych klasyfikacjach, jak na przykład Trends in International Math and Science Study (TIMSS) badającym umiejętności z zakresu nauk ścisłych (czołowe miejsca w latach 1995, 1999, 2005 i 2007), czy w analizującym umiejętności z zakresu czytania i rozumienia tekstu Progress in International Reading Literacy Study (PIRLS) (czwarte miejsce zarówno w 2006, jak i w 2011 roku) ${ }^{15}$.

\section{Nauczyciele - serce przemian i postępu}

Potencjał szkoły wyłania się z potencjału nauczycieli, którzy są najbardziej wartościowym jej zasobem ${ }^{16}$. Władze Singapuru przyjmują jednak $\mathrm{w}$ tym zakresie znacznie szerszą, niż tradycyjna, perspektywę. Nauczyciele w tym kraju są bowiem w jednakowej mierze zarówno największym atutem szkoły, jak i całego społeczeństwa, przygotowując obywateli Singapuru do stojących przed nimi kluczowych z perspektywy przyszłości całego kraju wyzwań. Uznanie przewodniej roli nauczycieli znajduje odzwierciedlenie w słynnych już słowach, wypowiedzianych w latach dziewięćdziesiątych XX wieku przez premiera Singapuru Goh Chok Thong'a, który stwierdził, że „bogactwo narodu tkwi w jego obywatelach"17. Misją singapurskich nauczycieli i, z bardziej ogólnego punktu widzenia, całego tamtejszego systemu edukacji jest, w związku z powyższym, kształtowanie (formowanie) przyszłych losów narodu poprzez zapewnienie najlepszych możliwości edukacyjnych poszczególnym jego młodym przedstawicielom - dzieciom i młodzieży, którzy obejmą kiedyś władzę i staną się tym samym odpowiedzialni za podejmowanie decyzji wyznaczających losy swoich rodaków ${ }^{18}$.

System kształcenia i dokształcania nauczycieli w Singapurze jest przykładem sprawnego diagnozowania i rozwijania talentów oraz sprawnego inwestowania $\mathrm{w}$ obszary, które najefektywniej sprzyjają wysokiej jakości procesom edukacyjnym. Prowadząc $\mathrm{w}$ przemyślany sposób ze skrupulatną dokładnością przez kolejne etapy rozwoju akademickiego oraz osobistego uzyskuje się trafną, bazującą na rozwiniętej samoświadomości i samowie-

${ }^{14}$ IBE, Program Międzynarodowej Oceny Umiejętności Uczniów. Wyniki Badania 2015 w Polsce, Warszawa 2016, s. 3-4.

${ }_{15}$ OECD, Lessons from PISA for the United States, Strong Performers and Succesful Reformers in Education, Paris 2011, s. 160; E.-L. Low, O.-S. Tan, Teacher Education Policy, s. 12.

${ }^{16}$ Ch. Day, Rozwój zawodowy nauczyciela, Gdańsk 2004, s. 17.

17 Za: OECD, Lessons from PISA for the United States, s. 165.

${ }^{18}$ E.-L. Low, O.-S. Tan, Teacher Education Policy, s. 13. 
dzy, decyzję, odnoszącą się do wyboru preferowanej ścieżki rozwoju zawodowego. System singapurski obfituje bowiem w mnogość rozwiązań, których głównym zadaniem jest wspieranie zdiagnozowanych mocnych stron studentów (oczywiście, także z uwzględnieniem potrzeby dbania o postępy w słabszych obszarach), przy jednoczesnym zapewnieniu optymalnych warunków wzmacniania potencjału i rozwoju talentów - w tym talentów pedagogicznych.

Utrzymanie przez Singapur pozycji lidera nowoczesności i konkurencyjności (zarówno w skali lokalnej, jak i globalnej) jest jednym z głównych zadań nieustanne udoskonalanego procesu kształcenia i doskonalenia nauczycieli. Przejawem tego wciąż niedocenianego w wielu systemach edukacyjnych sposobu postrzegania roli nauczyciela we współczesnym społeczeństwie był zapoczątkowany w drugiej połowie lat dziewięćdziesiątych XX wieku program "Myśląca Szkoła, Uczący się Naród” (Thinking School, Learning Nation), w ramach którego singapurskie Ministerstwo Edukacji Narodowej (Ministry of Education - MOE) zaczęło promować nauczycieli jako profesję będącą rdzeniowym ogniwem procesu przemian - ogniwem stanowiącym przykład godny naśladowania w procesie innowacji, generowania nowych pomysłów, efektywnego nauczania i uczenia się oraz ustawicznego rozwoju ${ }^{19}$.

W 1991 roku, decyzją singapurskiego rządu, z połączenia powstałego w 1973 roku Instytutu Edukacji (Institute of Education) oraz założonego w 1984 roku Kolegium Edukacji Fizycznej (The College of Physical Education), utworzony został Narodowy Instytut Edukacji (National Institute of Education - NIE) - autonomiczna jednostka (właściwie - instytut naukowy) działająca w ramach Uniwersytetu Technologicznego Nanyang ${ }^{20}$ (uznanego obecnie za czwartą najlepszą uczelnię na świecie w kategorii „Inżynieria i Technologia”, 22. w kategorii „Nauki społeczne i zarządzanie” (w ramach tej kategorii 18. miejsce na świecie w podkategorii „Edukacja” ${ }^{21}$, ściśle współpracująca ze szkołami na terenie całego kraju (warto nadmienić, że w 2015 roku w Singapurze działało 336 szkół różnych szczebli, co w należyty sposób pokazuje zasięg i rozmiar wspomnianej kooperacji $)^{22}$. Należy podkreślić, że powołanie Instytutu jest uznawane za jeden $\mathrm{z}$ kluczowych kamieni milowych w długofalowym procesie budowania i reformowania systemu edukacji niepodległego Singapuru ${ }^{23}$. Kwestię zatrudniania nauczycieli można zatem, w przypadku Singapuru, ująć w następujący sposób - nauczycieli zatrudnia co prawda Mi-

${ }^{19}$ S.K.S. Tan i in., The Qualifications of the Teaching Force: Data From Singapore, [w:] A Comparative Study of Teacher Preparation and Qualifications in Six Nations, Philadelphia 2007, s. 71.

${ }^{20}$ E.-L. Low, O.-S. Tan, Teacher Education Policy, s. 20. 35,42 .

${ }^{21}$ Quacquarelli Symonds, QS World University Rankings by Subject 2017, London 2017, s. 17,

${ }^{22}$ E.-L. Low, O.-S. Tan, Teacher Education Policy, s. 11-12.

${ }^{23}$ NIE, A Teacher Education Model for the 21st Century, Singapore 2009, s. 16-19. 
nisterstwo Edukacji, ale już ich adekwatne do bieżących potrzeb i wymagań systemu przeszkolenie i przygotowanie do pracy zawodowej pozostaje właśnie $w$ gestii Instytutu (rokrocznie organizowane $w$ jego ramach szkolenia kończy około dwa tysiące nauczycieli), jako jedynej w skali całego kraju jednostki dysponującej uprawnieniami do kształcenia nauczycieli ${ }^{24}$. Obie wspomniane instytucje pozostają w szczególnej formie symbiozy, działając wespół w wielu obszarach, a ich współpraca obejmuje przede wszystkim kształcenie przyszłych nauczycieli oraz dokształcanie i doskonalenie tych, którzy są już aktywni na rynku pracy. Przedstawiciele NIE i MOE wspólnie biorą udział $\mathrm{w}$ pracach mających na celu opracowanie standardów branych pod uwage w procesie rekrutacji nauczycieli oraz czynnie uczestniczą we właściwej procedurze selekcji. Pracownicy NIE, będąc powszechnie uznanymi autorytetami w zakresie trudności realnie występujących w obszarze codziennej praktyki nauczycielskiej, uczestniczą także, na zaproszenie MOE, w cyklicznych spotkaniach roboczych odnoszących się do ewentualnych zmian w programach kształcenia i dokształcania nauczycieli. Co oczywiste, ich opinia jest zawsze brana pod uwagę i stanowi swoistą rekomendację dla inicjatyw planowanych w tej sferze przez Ministerstwo. Dokonywanie rewizji modułów szkoleniowych jest niezbędne z perspektywy tak charakterystycznego dla Singapuru ustawicznego rozwoju (którego nieodłącznym elementem jest stałe dostosowywanie treści i metod kształcenia do szybko zmieniających się wymagań rynku pracy oraz nowych problemów czy trudności w realizacji szkolnych zadań zawodowych, co stanowi swego rodzaju urzeczywistnienie wspomnianej już wcześniej utopii wolnego rynku $)^{25}$. Z uwagi na fakt, że profesorowie NIE są regularnie angażowani w dyskusje i decyzje ministerialne, to procedury i kierunki działań Narodowego Instytutu Edukacji stosunkowo często pozostają w zgodności z polityką ministerialną. Generalnie rzecz ujmując, kształcenie nauczycieli w ramach NIE, bazujące na wizji ukutej w MOE (we wspomnianej już kooperacji z przedstawicielami Instytutu), ma na celu stworzenie społeczeństwa składającego się z myślących i zaangażowanych w realizację wspólnego dobra obywateli, którzy w procesie edukacji zostaną wyposażeni $\mathrm{w}$ wiedzę, umiejętności i kompetencje społeczne niezbędne do stałego wnoszenia wkładu w rozwój swojej ojczyzny. Obywateli, którzy korzystając $z$ wszechstronnych programów nauczania nastawionych przede wszystkim na trafną identyfikację oraz optymalne wykorzystanie i rozwinięcie potencjału drzemiącego w każdym z uczniów/studentów, będą mogli stać się kreatywnymi twórcami nowych rozwiązań (nie tylko w sferze edu-

${ }^{24}$ T.L. Choo, L. Darling-Hammond, Creating Effective Teachers and Leaders in Singapore, [w:] Teacher and Leader Effectiveness in High-Performing Education Systems, red. L. Darling-Hammond, R. Rothman, California 2011, s. 35.

${ }^{25}$ S.K.S. Tan i in., The Qualifications, s. 75. 
kacji), czy osobami kierującymi procesami wprowadzania dalszych reform $\mathrm{w}$ tym i tak już błyskawicznie rozwijającym się kraju (tzw. liderzy zmian) ${ }^{26}$.

Singapur wypracował unikalny system zintegrowanego planowania. Współpraca Ministerstwa Edukacji z Narodowym Instytutem Edukacji, jednostką kształcącą nauczycieli, oraz z singapurskimi szkołami jest przykładem dbałości o silny związek teorii z praktyką bazujący na właściwym zrozumieniu ich kluczowej dla powodzenia omawianych procesów relacji ${ }^{27}$. W modelu singapurskim teoria i praktyka nieustannie wzajemnie się przenikają i wpływają na doskonalenie rzeczywistości szkolnej w niekończącym się procesie adaptacji procesów nauczania-uczenia się do wymagań i nowych wyzwań współczesnego świata. Jest także przykładem realności politycznej wizji zorientowanej na dobro społeczne, a nie partykularne interesy grupy rządzącej. W efekcie, zdolność rządu do skutecznego zarządzania podażą i popytem na edukację i umiejętności jest głównym źródłem konkurencyjnej przewagi Singapuru.

Od lat dziewięćdziesiątych wykwalifikowani już nauczyciele i liderzy szkół tworzą kamień węgielny systemu edukacji i są głównym przyczynkiem jego wysokiej jakości oraz efektywności. Zamiast skupiać się na jednym elemencie, Singapur opracował wszechstronny system doboru, kształcenia, wynagradzania i rozwoju nauczycieli i dyrektorów, tworząc tym samym ogromny potencjał gotowy do wykorzystania w momencie kontaktu $\mathrm{z}$ uczniem. Jednocześnie, jest to jeden $z$ najbardziej rygorystycznych na świecie systemów kształcenia nauczycieli.

\section{Rekrutacja - wyłanianie najlepszych z najlepszych}

W Singapurze wejście $\mathrm{w}$ profesję nauczycielską wymaga spełnienia niezwykle wysokich standardów oraz warunków wstępnych. Z tego względu, rekrutacja do zawodu nauczyciela $\mathrm{w}$ tym kraju bywa często określana mianem „agresywnej” ${ }^{28}$. Pod uwagę brani są wyłącznie kandydaci najlepiej rokujący, bowiem uwaga instytucji rekrutujących jest skupiona na tych spośród aplikujących uczniów, których można zaliczyć do grupy zrzeszającej absolwentów wszystkich typów szkół, uzyskujących najwyższe wyniki w dotychczasowej nauce (muszą plasować się w grupie liczącej ok. 30\% uczniów uzyskujących najlepsze oceny końcowe ${ }^{29}$ i są najlepiej rokującymi uczniami klas

\footnotetext{
${ }^{26}$ E.-L. Low, O.-S. Tan, Teacher Education Policy, s. 15.

27 Por. NIE, A Teacher Education Model for the 21st Century, s. 40-41, 62-73.

28 S.K.S. Tan i in., The Qualifications, s. 71.

${ }^{29}$ Por. E.-L. Low, O.-S. Tan, Teacher Education Policy, s. 13-14.
} 
wieńczących na szkołę średnią ${ }^{30}$ - sprostanie tym bazującym na dotychczasowych osiągnięciach akademickich wymogom oznacza przejście pierwszego etapu rekrutacji. W procesie tym potencjalni nauczyciele są starannie dobierani przez gremia złożone z dyrektorów szkół.

Warto podkreślić, iż proces rekrutacji nie oznacza wyłącznie pozyskania uczniów z najwyższymi osiągnięciami szkolnymi. Muszą to być jednocześnie osoby zaangażowane $\mathrm{w}$ inne aktywności na rzecz, mówiąc ogólnie, dobra społeczności singapurskiej, które w służbie narodu odnajdują swoją misję. Za rekrutację oraz późniejsze szkolenie, certyfikację (nadawanie niezbędnych uprawnień) i rozmieszczenie przyszłych nauczycieli w konkretnych placówkach odpowiada singapurskie Ministerstwo Edukacji, które dla potencjalnych kandydatów regularnie organizuje specjalne seminaria, znane pod nazwą Teaching as a Career („Nauczanie jako kariera”) - w ich trakcie uczestnicy (biorący aktywny udział w spotkaniu, co znajduje wyraz m.in. zadawaniu pytań) otrzymują kluczowe informacje dotyczące najistotniejszych z perspektywy kandydatów do tego zawodu, różnorodnych aspektów pracy nauczyciela ${ }^{31}$. Ponadto, prowadzona jest również rekrutacja internetowa, co stanowi swoisty znak czasu i jest kolejnym przykładem tego, jak bardzo singapurskie Ministerstwo Edukacji jest zdeterminowane, by dotrzeć do wszystkich potencjalnych kandydatów do nauczycielskiej profesji. W cały ten proces Ministerstwo angażuje inne instytucje oraz grupy osób, z którymi współpracuje, tworząc dosłownie i w przenośni „sieć wyławiającą najlepszych". Kooperacja prowadzona jest ze szkołami, nauczycielami, rodzica$\mathrm{mi}$, uniwersytetami, firmami prywatnymi, pozostałymi ministerstwami oraz $\mathrm{z}$ najważniejszą instytucją $\mathrm{w}$ systemie kształcenia i doskonalenia nauczycieli - Narodowym Instytutem Edukacji3 ${ }^{32}$. Należy wyraźnie podkreślić, że każdego roku, korzystając z informacji zwrotnych płynących z placówek edukacyjnych, Ministerstwo Edukacji tworzy strategiczne dla dalszego rozwoju całego systemu prognozy, odnoszące się, między innymi, do kolejnych edycji rekrutacji do zawodu nauczyciela, konieczności tworzenia nowych szkół, czy przygotowywania nowych programów nauczania oraz różnorodnych, niezbędnych we wskazanym przez zainteresowanych obszarze, inicjatyw edukacyjnych $^{33}$.

Analiza założeń wstępnego etapu doboru do pracy w placówkach singapurskiego systemu oświaty skłania do refleksji nad kwestią niezwykle istotną - w jaki sposób singapurskim włodarzom udaje się zachęcić do wyboru nauczycielskiej ścieżki zawodowej tych absolwentów, którzy ze względu na

\footnotetext{
${ }^{30}$ OECD, Lessons from PISA for the United States, s. 169.

${ }^{31}$ E.-L. Low, O.-S. Tan, Teacher Education Policy, s. 16.

32 S.K.S. Tan i in., The Qualifications, s. 74.

${ }^{33}$ E.-L. Low, O.-S. Tan, Teacher Education Policy, s. 16.
} 
wyróżniające osiągnięcia $\mathrm{w}$ dotychczasowej nauce mają wszelkie atuty, by ubiegać się o pracę $\mathrm{w}$ innych, często znacznie atrakcyjniejszych ze względu na ewentualne zarobki profesjach. Nie ulega wątpliwości, że rozwiązania wypracowane i stosowane w Singapurze w tym konkretnym obszarze zasługują na szczególną uwagę. Kluczowy wydaje się fakt, że zawód nauczyciela jest tam uznawany za niezwykle prestiżowy, co wynika przede wszystkim z umiejętnie prowadzonej polityki rządu. Kolejny istotny czynnik stanowi to, że jedną z potencjalnych konsekwencji trudnej drogi do zawodu jest świadomość, że niewielu singapurskich nauczycieli decyduje się na rezygnację z pracy w szkole ${ }^{34}$ (w myśl ogólnej, popularnej w obszarze psychologii społecznej zasady: „im trudniej coś przychodzi, tym większą ma to wartość"). Istotną rolę w procesie utrzymania wysokiego prestiżu zawodu nauczycielskiego odgrywa bez wątpienia konsekwentna polityka odnosząca się do wynagrodzeń w sektorze edukacji. W Singapurze bowiem dawno już zrozumiano, że jeśli nauczyciele mają efektywnie realizować stawiane przed nimi cele, odnoszące się w szerszej perspektywie do zapewnienia warunków niezbędnych dla sukcesu całego państwa i narodu, to podejmowane przez nich wysiłki bezapelacyjnie muszą pociągać za sobą odpowiadającą im, odpowiednio wysoką gratyfikację. Niewątpliwie wielce krótkowzroczne byłoby oczekiwanie wysokiego poziomu satysfakcji z wykonywanej pracy, jeśli, zwłaszcza w kontekście odnoszonych sukcesów, pracownik miałby świadomość, że pensja, którą otrzymuje za swoje wysiłki jest zbyt niska w stosunku do jego kompetencji, pokładanych w nim nadziei oraz spoczywającej na nim odpowiedzialności (co wiąże się z ogromną presją stanowiącą niebagatelne obciążenie z perspektywy psychicznego dobrostanu), czy choćby z punktu widzenia nakładu czasu i energii nieodzownych w procesie sumiennego wykonywania powierzonych mu licznych zadań.

Kandydaci do zawodu - przyszli nauczyciele, którzy pomyślnie pokonali etap rekrutacji i zostali skierowani na dalsze szkolenie (w NIE), otrzymują każdego miesiąca stypendium odpowiadające swoją wysokością średniej pensji, jaką otrzymują absolwenci uniwersytetów i pozostałych typów szkół, którzy wybrali inną ścieżkę zawodową ${ }^{35}$ - studia nauczycielskie są zatem wysoce konkurencyjne $\mathrm{w}$ stosunku do pozostałych opcji rozwoju. W zamian za tak rozbudowany system finansowego wsparcia, absolwenci NIE muszą zobowiązać się do nauczania przez co najmniej trzy lata (swego rodzaju zabezpieczenie zwrotu poniesionych przez państwo kosztów). Ponadto, każda osoba zatrudniona na stanowisku nauczyciela stażysty cieszy się w Singapurze statusem pełnoprawnego pracownika służby cywilnej

\footnotetext{
${ }^{34}$ S.K.S. Tan $\mathrm{i}$ in., The Qualifications, s. 71.

35 OECD, Lessons from PISA for the United States, s. 169.
} 
(General Eduction Officer) zatrudnianego przez ministerstwo, czego rezultatem jest nie tylko otrzymywanie stosunkowo wysokiej miesięcznej pensji, ale także pełnego zestawu różnorodnych świadczeń socjalnych, dodatków motywacyjnych, czy premii za wysokie osiągnięcia ${ }^{36}$. Dbałość o utrzymanie konkurencyjności profesji nauczycielskiej znajduje swój wyraz między innymi $\mathrm{w}$ prowadzonym przez MOE stałym monitoringu wynagrodzeń $\mathrm{w}$ innych sektorach $-\mathrm{w}$ razie potrzeby nauczycielskie wynagrodzenie jest podnoszone do poziomu, który gwarantuje atrakcyjność uzyskiwanych dochodów ${ }^{37}$.

Jeśli weryfikacja dotychczasowych osiągnięć akademickich kandydata uzyska status pozytywny, zostaje on zakwalifikowany do etapu drugiego. Bazując na rygorystycznym i skrupulatnie przeprowadzonym wywiadzie (stanowiącym centralne ogniwo tego etapu), urzędnicy MOE uzyskują dane niezbędne do wyciągnięcia wniosków dotyczących kluczowych, pozaakademickich kompetencji kandydata do zawodu. Informacje gromadzone przez urzędników obejmują, między innymi, następujące czynniki (grupy czynników): pasję do nauczania, kompetencje interpersonalne (społeczne), umiejętność kreatywnego i innowacyjnego myślenia, pewność siebie i poczucie własnej skuteczności, kompetencje przywódcze, czy ogólnie pojmowane predyspozycje do stania się $\mathrm{w}$ przyszłości godnym wzorem do naśladowania przez uczniów ${ }^{38}$. Co niezwykle istotne, zwłaszcza w świetle licznych badań psychologicznych wskazujących na kluczową rolę czynników wewnętrznych w efektywnym sprawowaniu funkcji zawodowej nauczyciela ${ }^{39}$, wspomniany wywiad uwzględnia także szeroką diagnozę osobowości kandydata oraz specjalnie przygotowany zestaw zadań praktycznych. Efektem opisanej procedury jest odrzucenie około $80 \%$ indagowanych na tym etapie. Ostatecznie około 16-17\% osób z pierwotnej grupy, która zgłosiła się do etapu pierwszego, zostaje tak zwanymi kandydatami na nauczycieli i rozpoczyna właściwe szkolenie $^{40}$.

${ }^{36}$ E.-L. Low, O.-S. Tan, Teacher Education Policy, s. 17.

${ }^{37}$ Średnie roczne zarobki nauczycieli w Singapurze, po uwzględnieniu parytetu siły nabywczej, wynoszą 46 tys. dolarów brutto - wynika z raportu "Global Teacher Status Index" przygotowanego przez Varkey GEMS Foundation. To najlepszy wynik wśród 21 rozwiniętych krajów świata, za: OECD, Lessons from PISA for the United States, s. 169.

${ }^{38}$ S.K.S. Tan i in., The Qualifications, s. 74.

39 Por. A. Eryilmaz, A. Kara, Comparison of Teachers and Pre-Service Teachers With Respect to Personality Traits and Career Adaptability, International Journal of Instruction, 2017, 10, 1, s. 86. Por. S.T. Kwiatkowski, Osobowość studentów pedagogiki w świetle Pięcioczynnikowego Modelu Osobowości, Ruch Pedagogiczny, 2014, 1, s. 73-76.

${ }^{40}$ A. Karpati, Teacher training and professional development, [w:] Green Book. For the renewal of public education in Hungary, red. K. Fazekas, J. Köllô, J. Varga, Budapest 2009, s. 215. 


\section{Proces kształcenia nauczycieli}

Pomyślne przejście etapu drugiego, skoncentrowanego przede wszystkim na kluczowych z punktu widzenia nauczycielskiej efektywności, szeroko pojmowanych właściwościach wewnętrznych, jest równoznaczne z rozpoczęciem przez kandydatów właściwego procesu kształcenia do przyszłej pracy w szkole, prowadzonego przez wzmiankowany już wcześniej Narodowy Instytut Edukacji, działający w ramach Uniwersytetu Technologicznego Nanyang. Osoby zakwalifikowane do uczestnictwa w tym niezwykle wymagającym kursie rozpoczynają studia licencjackie lub magisterskie - kryterium jest tu ich wyjściowy poziom wykształcenia. Proces kształcenia adeptów do zawodu nauczyciela może przybierać różną formę, w zależności od ich dotychczasowej ścieżki akademickiej ${ }^{41}$, i trwać od roku do czterech lat ${ }^{42}$. Wszystko zależy od dyplomu, z którym absolwenci szkół trafiają do Instytutu. Świadectwo ukończenia szkoły technicznej wiąże się z innym typem kursu niż na przykład profil akademicki.

Wszyscy studenci zapoznają się z singapurskim programem nauczania. Jako że głównym celem NIE jest szkolenie wszystkich singapurskich nauczycieli, nie istnieją podziały na nauki humanistyczne i ścisłe, nie ma też wydziałów pedagogiki. Wypracowane w Singapurze programy kształcenia nauczycieli wyróżnia brak podziałów na konkretne kursy, dokonywanego ze względu na to, czy dotyczą one zajęć kierunkowych (tzw. sciences), poświęcone są szeroko rozumianej sztuce (arts), czy typowo pedagogicznym zagadnieniom (np. dotyczącym metodyki pracy z uczniem). Takie nietypowe rozwiązanie umożliwiło uniknięcie przyszłych, potencjalnych, choć wysoce prawdopodobnych sporów mogących mieć swe źródło w różnych odmiennych priorytetach - rozbieżnych, w zależności od osoby opiniach na temat rodzaju zajęć, na które uczęszczać powinni kandydaci na przyszłych nauczycieli. Według Lee Sing Konga, konflikty priorytetowe, które są obecne w wielu programach kształcenia nauczycieli zachodnich, są mniej znaczące, a dzięki temu znaczenia nabierają treści pedagogiczne ${ }^{43}$.

NIE wdrożyła macierzową strukturę organizacyjną, dzięki której biura programowe (np. Biuro Kształcenia Nauczycieli - Office for Teacher Education) współpracują z poszczególnymi grupami akademickimi przy opracowywaniu wstępnych programów szkoleniowych dla nauczycieli. Oznacza to, że programy są projektowane z myślą o nauczycielu, a nie w celu zaspokojenia

${ }^{41}$ UNESCO International Bureau of Education, World Data on Education - Singapore, Geneva 2011, s. 5-7.

${ }^{42}$ K.M. Lim, Teacher Education in Singapore, http://www.academia.edu/23996078/Teacher_Education_and_Teaching_Profession_in_Singapore - [dostęp: 25.09.2017], s. 2.

${ }^{43}$ OECD, Lessons from PISA for the United States, s. 169. 
interesów poszczególnych wydziałów akademickich. W związku z tym istnieje większy nacisk na zawartość pedagogiczną i większa synergia pomiędzy modułami w ramach poszczególnych programów. Co istotne - w NIE kandydaci uczą się tego, jak nauczać innych, według tych samych zasad, jakich urzeczywistnienia oczekuje się od nich później, kiedy rozpoczną już właściwą pracę $\mathrm{w}$ singapurskich placówkach edukacyjnych. Warto zatem $\mathrm{w}$ tym miejscu podkreślić z należytą starannością, że w singapurskim systemie kształcenia nauczycieli nie pozostawiono miejsca na przekazywanie umiejętności dydaktycznych czy metodycznych, które nie będą potem wykorzystywane w codziennej pracy szkolnej - wręcz przeciwnie, w programach nauczania znajdują się wyłącznie treści, co do których zastosowania w przyszłości nie ma żadnych wątpliwości. Wprowadzenie takiego optymalizującego funkcjonowanie singapurskich szkół rozwiązania jest po części możliwe dzięki temu, że w procesie kształcenia około 1/4 każdego z typów szkoleń stanowią praktyki szkolne, podczas których przyszli nauczyciele-stażyści mogą sukcesywnie rozwijać swoje umiejętności i cały, szeroko pojmowany warsztat pracy, pod nadzorem oferujących stałe wsparcie nauczycieli ${ }^{44}$. Takie podejście do obowiązkowych praktyk ułatwia kandydatom na nauczycieli prowadzenie samodzielnych obserwacji i, na ich podstawie, wyciąganie wniosków na temat najbardziej skutecznych (czyli jednocześnie najbardziej pożądanych) metod/technik/strategii działania i rozwiązywania problemów, na które mogą trafić w podczas przyszłej pracy zawodowej.

Szczególna uwaga należy się niewątpliwie także wypracowanym w modelu singapurskim warunkom do nauki i rozwoju, które Narodowy Instytut Edukacji zapewnia kandydatom na nauczycieli. Warto w tym miejscu wspomnieć choćby o tym, że każdy z nich otrzymuje na początku kursu laptop, z którego może korzystać przez cały okres pobierania nauki w Instytucie. Nie stanowi to, co prawda, rozwiązania wyjątkowego w skali globalnej, ale warto zwrócić uwagę, że w tym przypadku zarówno komputer, jak i dostęp do Sieci (szybki i bezpłatny na terenie całego kampusu) zapewnia nieodpłatnie państwo. Podejście takie wynika z uznania istotnej roli kształcenia w sferze świata cyfrowego i niewątpliwie wymaga nakładów finansowych. Instytut zapewnia ponadto swoim studentom przestrzeń niezbędną do twórczej i efektywnej pracy - tak indywidualnej, jak i grupowej. Poszczególne obiekty kampusu zostały zaprojektowane specjalnie z myślą o tym, by zapewnić przyszłym nauczycielom możliwość prowadzenia działań o charakterze zespołowym - są tam zatem dające niezbędny komfort podczas długich dyskusji pomieszczenia dźwiękoszczelne. Znaleźć w nich można okrągłe stoły, sprzyjające współpracy i grupowemu stawianiu czoła wyzwaniom, wygodne

\footnotetext{
${ }^{44}$ S.K.S. Tan i in., The Qualifications, s. 76.
} 
sofy i fotele oraz najnowocześniejszy sprzęt multimedialny czy interaktywne tablice ${ }^{45}$. Singapurscy kandydaci na nauczycieli dysponują więc zapleczem umożliwiającym całkowite poświęcenie się zdobywaniu wiedzy i kolejnych wartościowych doświadczeń, bez konieczności zaprzątania sobie głowy kwestiami drugoplanowymi - a taką może być na przykład kłopot z dostępem do niezbędnego sprzętu czy sali warsztatowej, oznaczający trwonienie cennego, spędzanego $\mathrm{w}$ Instytucie czasu na zajmowanie się sprawami technicznymi bądź wypełnianie kolejnych dokumentów umożliwiających wypożyczenie deficytowego sprzętu czy rezerwację jednej z nielicznych, obleganych przez studentów pokojów pracy wspólnej. Zapewnienie bazy i odpowiednich warunków do nauki stanowi dla włodarzy Instytutu niekwestionowaną oczywistość. Kandydaci na nauczycieli muszą bowiem umieć korzystać z takiego zaplecza, z jakiego w przyszłości będą korzystać ich uczniowie. Podobnie rzecz dotyczy współpracy. I tu zapewnienie niezbędnych warunków do efektywnej pracy zespołowej stanowi zarówno element doskonalenia procesu kształcenia (synergia), jak i przygotowania przyszłych nauczycieli do kultury współpracy obecnej w singapurskich szkołach (dobrym przykładem są opisane w dalszej części artykułu Professional Learning Communities lub Teacher's Network).

W efekcie wspomnianej już, obejmującej szeroki zakres obszarów, współpracy Instytutu i Ministerstwa Edukacji, każdy nauczyciel, który z powodzeniem zakończył swój udział w którykolwiek z prowadzonych w NIE kursów, niezwłocznie, niejako z urzędu, otrzymuje odpowiedni certyfikat uprawniający go do podjęcia pracy w placówkach singapurskiego systemu edukacji. Przyjęte w NIE standardy nauczania, ustawicznie modyfikowane w celu ich optymalnego dostosowania do stale zmieniających się wymagań i stojących przed nauczycielami oraz szkołami wyzwań, są skonstruowane w sposób, który sprawia, że absolwenci organizowanych przez tę placówkę szkoleń nie muszą zdawać żadnych dodatkowych egzaminów i/lub uzyskiwać dodatkowych uprawnień czy kompetencji (poza, co oczywiste, różnymi formami kształcenia ustawicznego $)^{46}$.

\section{Doskonalenie nauczycieli i pomoc „na starcie”}

Typowa dla modelu singapurskiego szeroka oferta programów mających na celu zapewnienie nauczycielom niezbędnego wsparcia oraz odpowiednich warunków do codziennej pracy, tworzy warunki nieodzowne w procesie wymaganego od nich na każdym etapie ich zawodowej ścieżki, ustawicznego

45 T.L. Choo, L. Darling-Hammond, Creating Effective Teachers and Leaders, s. 35.

${ }^{46}$ S.K.S. Tan i in., The Qualifications, s. 75; OECD, Lessons from PISA for the United States, s. 169. 
rozwijania własnego potencjału. Jednym z kluczowych elementów tego jakże rozwiniętego "systemu wsparcia” jest niewątpliwie to, że singapurscy nauczyciele otrzymują każdego roku do swojej dyspozycji sto godzin, które mogą (i jednocześnie mają obowiązek) wykorzystać poprzez uczestnictwo w organizowanych przez państwo, licznych i różnorodnych formach dokształcania i doskonalenia zawodowego. Chodzi tu przede wszystkim o dostęp do całego wachlarza kursów, warsztatów, szkolen, tematycznych konferencji i seminariów, zaprojektowanych po to, żeby urzeczywistniać jeden z filarów singapurskiego sukcesu systemu edukacji, jakim jest wspieranie ustawicznego, wielopłaszczyznowego rozwoju pracowników oświaty. Do grupy czynników mających wpływać na realizację wspomnianego celu należy także przysługujące każdemu z singapurskich nauczycieli prawo do urlopu naukowego, który powinien zostać przez nich wykorzystany na wszechstronny rozwój - między innymi poszerzanie wiedzy oraz wzmacnianie swoich umiejętności i kompetencji społecznych kluczowych z punktu widzenia pracy z dziećmi i młodzieżąa ${ }^{47}$ Na wysoką jakość systemu doskonalenia nauczycieli w Singapurze niepodważalny wpływ ma również to, że oferta programowa odnosząca się do ustawicznego rozwoju jest dostępna dla wszystkich pedagogów, niezależnie od ich dotychczasowego stażu pracy. A zatem, na wsparcie $\mathrm{W}$ analizowanym zakresie liczyć mogą nie tylko początkujący nauczyciele, dopiero rozpoczynający pierwszą w swej karierze szkolnej pracę (tuż po zakończeniu kształcenia w Narodowym Instytucie Edukacji), ale także mający już określony staż pracy w zawodzie, choć z drugiej strony system obejmuje także pewne formy wspierania nauczycieli, które skierowane są wyłącznie do nauczycieli rozpoczynających prace w zawodzie - jak choćby opisany w dalszej części niniejszego tekstu mentoring.

W Singapurze aż 99\% nauczycieli rozpoczynających pracę w danej szkole bierze udział w różnorodnych aktywnościach wprowadzających, podczas gdy średni wynik uzyskany w innych państwach biorących udział w badaniach TALIS to zaledwie $44 \%{ }^{48}$. Singapurscy pedagodzy uczestniczą $\mathrm{w}$ programach wprowadzających organizowanych zarówno przez państwo (skala globalna), jak i przez szkoły (skala lokalna), do których skierowano ich po ukończeniu kształcenia w NIE. Każdy z nich bierze na poziomie centralnym udział w trzydniowym „Programie Orientacyjnym dla Początkujących Nauczycieli", prowadzonym przez Ministerstwo Edukacji. Uwzględnia on szereg kursów i warsztatów, które mają za zadanie przede wszystkim konsolidację ich dotychczasowej wiedzy oraz położenie szczególnego nacisku na konieczność dbania o wszechstronny rozwój uczniów (kluczowy element singapurskiego s. 36 .

${ }^{47}$ Tamże, s. 169; T.L. Choo, L. Darling-Hammond, Creating Effective Teachers and Leaders,

${ }^{48}$ OECD, Singapore - Country Note - Results for TALIS 2013, Paris, 2014, s. 1. 
systemu), a także wprowadzenie ich w tajniki profesji (m.in. wskazanie im pożądanych postaw, systemów wartości, czy konkretnych zachowań, jakie powinni prezentować w swej codziennej działalności) ${ }^{49}$. Głównym celem tego typu szkoleń jest przekazanie nowym nauczycielom swoistego know how szeroko pojmowanej „instrukcji obsługi szkoły”, której zadaniem jest sprawienie, by w procesie aklimatyzacji uniknąć niepotrzebnych nieporozumień, błędów i konfliktów oraz, co niezwykle istotne, zminimalizować ryzyko wystąpienia towarzyszącego tym zjawiskom stresu zawodowego, tak charakterystycznego przecież dla każdego człowieka dopiero rozpoczynającego swą zawodową drogę $e^{50}$.

Pełne uzasadnienie $\mathrm{w}$ faktach znajdzie niewątpliwie przyjęcie założenia, że do elementów rdzeniowych procesu, którego zasadniczym zadaniem jest zapewnienie początkującym nauczycielom stosunkowo łatwego i wolnego od niepotrzebnego stresu startu $\mathrm{w}$ zawodzie, jest profesjonalny mentoring. Singapurski system wypracował $\mathrm{w}$ tym zakresie bardzo ciekawe rozwiązania - każdemu świeżo upieczonemu absolwentowi NIE przydzielany jest do pomocy doświadczony kolega/doświadczona koleżanka. Mentorem może zostać nauczyciel o co najmniej pięcioletnim doświadczeniu w zawodzie, który, po przejściu odpowiedniego przeszkolenia (przeprowadzonego w NIE), ma stać się przewodnikiem dla swojego stawiającego pierwsze kroki w zawodzie współpracownika - ma wprowadzić go w świat danej szkoły i przekazać mu wiedzę oraz umiejętności kluczowe z perspektywy efektywnego w nim funkcjonowania. Równie istotne jest przełożenie na język praktyki tajników sprawnego poruszania się $\mathrm{w}$ nowej, niejednokrotnie generującej sytuacje trudne rzeczywistości. W celu standaryzacji procedury mentoringu, zaprojektowano tak zwany Ustrukturalizowany Program Przygotowania do Mentoringu (Structured Mentorship Preparation Programme), którego zasadniczym celem jest przygotowanie przyszłego mentora do nowej, niezwykle odpowiedzialnej roli51.

Młodzi nauczyciele, poddani trwającym dwa lata procesom mentoringu oraz coachingu (trenowania), wdrażają się do rozpoczęcia efektywnej pracy zawodowej. Oczywiście, w tym czasie mentorzy pomagają im w stopniowym odkrywaniu tajników rzemiosła i opanowywaniu kolejnych kluczowych dla efektywnej pracy umiejętności. Równolegle młodzi nauczyciele uczestniczą w przygotowanych z myślą o nich kursach i szkoleniach prowadzonych przez Instytut (NIE) lub Ministerstwo (MOE). Oferta dotyczy, między innymi, za-

${ }^{49}$ OECD, TALIS 2013 Results: An International Perspective on Teaching and Learning, Paris, 2014, s. 90.

${ }^{50}$ Por. D. Walczak, Początkujacy nauczyciele. Raport z badania jakościowego, Warszawa 2012, s. 89-98.

${ }^{51}$ NIE, A Teacher Education Model for the 21st Century, s. 6. 
rządzania klasą (np. procesami grupowymi), szeroko pojmowanego doradztwa (w tym zawodowego), procedury rzetelnego i sprawiedliwego oceniania postępów uczniów, czy refleksyjnej praktyki. Każdy dostępny kurs odbywa się w sposób sprzężony z samym procesem mentoringu, co stanowi koronny argument za tezą, że podejście singapurskich władz do wprowadzania młodych, początkujących nauczycieli do zawodu ma charakter kompleksowych, starannie zaprojektowanych działań, tworzących swego rodzaju system naczyń połączonych, gdzie jakość każdego elementu ma wpływ na pozostałe części całej interesującej nas struktury. Trzeba przy tym dodać, że podczas tego "startu w zawodzie" początkujący nauczyciele otrzymują niższe obciążenie dydaktyczne (zazwyczaj 2/3 standardowego czasu pracy nauczyciela o dłuższym stażu). Istotą takiego podejścia jest ułatwienie im koncentracji na zadaniach związanych nie tylko z samym, tradycyjnie rozumianym, procesem dydaktycznym, ale także na innych, równie kluczowych dla efektywnego funkcjonowania w środowisku szkolnym obszarach ${ }^{52}$. W tak zarysowany model wpisuje się także to, że singapurscy nauczyciele prowadzą tygodniowo średnio dwadzieścia godzin lekcyjnych, a oprócz tego dysponują jeszcze czasem, który co prawda spędzają w szkole (poza pewnymi wyjątkami), lecz nie prowadzą w jego ramach zajęć (tzw. non-teaching hours). Jest to o tyle istotne, że mają oni wówczas szansę, by na przykład lepiej przygotowywać się do czekających ich lekcji i wyzwań, jakim będą musieli stawić czoła w ich trakcie (co wydaje się oczywistą formą wykorzystania tego typu „wolnych" godzin), oraz by zaangażować się $w$ dyskusje i rozważania na tematy związane z pracą szkolną. Ta druga aktywność przyjmuje zazwyczaj formę spotkań z innymi nauczycielami, co sprzyja nie tylko wzajemnej wymianie doświadczeń, ale również zacieśnianiu współpracy i tworzeniu więzi, osobowych i osobistych relacji pomiędzy poszczególnymi członkami nauczycielskiej społeczności. Nauczyciele mogą też $w$ tym czasie hospitować inne lekcje w celu poszerzania swej wiedzy praktycznej na temat szeroko pojmowanego procesu nauczania-uczenia się $e^{53}$.

Godne szczególnej wzmianki jest to, że dwa lata, poświęcane przez początkujących nauczycieli na poznawanie otaczającej ich szkolnej rzeczywistości pod czujnym okiem gotowego służyć im pomocą i radą mentora, traktowane są w Singapurze jako okres próbny, będący jednocześnie oficjalnym przedłużeniem praktyk, odbywanych jeszcze $w$ trakcie kształcenia w NIE. Poczynione $w$ tym czasie postępy oraz osiągnięcia są traktowane jako najważniejsze kryterium pełnego dopuszczenia młodych nauczycieli do zawodu. Następująca po pierwszych dwóch latach pracy pozytywna ocena dotychczasowego

\footnotetext{
${ }^{52}$ T.L. Choo, L. Darling-Hammond, Creating Effective Teachers and Leaders, s. 36.

${ }^{53}$ Tamże, s. 37.
} 
poziomu wykonania zadań szkolnych jest więc równoznaczna z otrzymaniem etatu. Można to uznać za zamknięcie ostatniego, trzeciego etapu procedury selekcyjnej do profesji nauczycielskiej w Singapurze ${ }^{54}$.

\section{Proces doskonalenia - uczenie się we współpracy}

Analizując działania singapurskich władz na rzecz stworzenia efektywnego systemu kształcenia, dokształcania i doskonalenia nauczycieli, nie można pominąć istotnego elementu, jakim jest proces uczenia się od siebie w ramach szerokiej współpracy.

W wyniku bezpośredniej kooperacji i wymiany doświadczeń nauczyciele mogą wzbogacać oraz rozwijać niezbędne kompetencje. Praca zespołowa z powodzeniem wspiera rozwój osobowy na zasadzie aktywności nauczycielskich grup samopomocy i doradztwa. (...) Team teaching staje się kolejną możliwością tworzenia kultury pracy, w której nauczyciele uzyskują przestrzeń do rozwoju swoich osobistych wizji, pokonując stres i strach, czerpią energię i motywację do rozwoju własnego mistrzostwa ${ }^{55}$.

Na ten złożony mechanizm składają się w Singapurze dwie znaczące inicjatywy. Pierwsza to Nauczycielskie Sieci (Teacher's Network) powstała już w 1998 roku. Druga zaś, Profesjonalne Społeczności Uczenia się/Uczących się (Professional Learning Communities - PLC), stanowi pochodną upowszechnianej od 2004 roku przez premiera Lee Hsien Loong'a idei „Nauczać mniej. Uczyć się więcej”. Obie inicjatywy opierają się na synergicznych walorach współpracy, jednakże dotykają różnych obszarów. O ile Nauczycielskie Sieci w większym stopniu koncentrują się na diagnozowaniu i rozwiązywaniu problemów $\mathrm{w}$ miejscu ich zaistnienia $\mathrm{z}$ wykorzystaniem metody badania w działaniu, o tyle istota Profesjonalnych Społeczności Uczących się zogniskowana jest w większym stopniu na upowszechnianiu i wymianie dobrych praktyk celem rozwoju i doskonalenia warsztatu i tak świetnie wykształconych nauczycieli.

Zasadniczym zadaniem Nauczycielskiej Sieci jest wszechstronne wspomaganie i stwarzanie warunków koniecznych do inicjowanego przez samych nauczycieli rozwoju zawodowego poprzez wzajemne dzielenie się wiedzą, doświadczeniami, czy promowanie refleksyjnego działania. Wśród różnorodnych form działań prowadzonych w ramach funkcjonowania Sieci można znaleźć, między innymi, tak zwane „nauczycielskie kręgi uczenia się” (teacher learning circles), konferencje tematyczne, utworzenie strony internetowej gromadzącej niezbędne nauczycielom informacje, prowadzone przez nauczycieli

\footnotetext{
${ }^{54}$ Tamże, s. 36.

${ }^{55}$ I. Nowosad, Perspektywy rozwoju szkoty. Szkice z teorii szkoty, Warszawa 2003, s. 89.
} 
warsztaty, wydawanie licznych publikacji oraz organizowanie programów i szkoleń, których głównym zadaniem jest utrzymanie lub poprawa psychicznego dobrostanu uczestników. Zwłaszcza temu ostatniemu, z wymienionych powyżej typów działań, należy poświęcać coraz więcej uwagi - zawód nauczyciela jest bowiem obciążony dużym ryzykiem, ze względu na szczególne narażenie osób w nim pracujących, na różnorodne problemy natury psychologicznej, prowadzące między innymi do wypalenia zawodowego.

"Nauczycielskie kręgi uczenia się" stanowią w szkołach inicjatywę utworzoną z czterech do dziesięciu nauczycieli, którzy wraz z moderatorem identyfikują, a następnie poprzez dyskusje i tak zwany action research (badania ukierunkowane na rozwiązanie pilnych problemów) wspólnie zajmują się podniesioną przez jednego (lub większą liczbę) z członków sytuacją problemową. Zebrania kręgów odbywają się zwykle w ramach ośmiu sesji (każda $\mathrm{z}$ nich trwa dwie godziny) przez cztery do dwunastu miesięcy. Rolą moderatora jest ustawiczne zachęcanie członków kręgu do przyjmowania nie tylko roli osób uczących się - otwartych na proces zdobywania wiedzy i umiejętności, ale również osób umiejących włączyć się w konstruktywną krytykę, nie naruszając przy tym dobrostanu i poczucia bezpieczeństwa pozostałych członków grupy. Bardzo istotne w tym kontekście jest uruchomienie i podtrzymanie procesu swobodnej oraz nieskrępowanej wymiany opinii, pomysłów czy wniosków, a ponadto - dzielenie się z pozostałymi członkami kręgu własnymi zawodowymi doświadczeniami, odnoszącymi się do sukcesów i ponoszonych porażek. Zadaniem dyrektora jest zapewnienie warunków, w których nauczyciele mogą dyskutować nad ważnymi dla nich problemami oraz potencjalnymi rozwiązaniami. Podejście takie stanowi kluczowy element procesu, który ma prowadzić do wykształcenia u singapurskich pedagogów zdolności do działań kolektywnych oraz zachęcać do przyjęcia roli refleksyjnego praktyka, zgodnie z koncepcją Donalda A. Schöna ${ }^{56}$. Wartym uwagi następstwem funkcjonowania nauczycielskich kręgów uczenia się jest też sukcesywne budowanie poczucia indywidualnego sprawstwa poszczególnych uczestników, między innymi poprzez uświadamianie im, że sprawując powierzone im obowiązki szkolne, nie tylko przyczyniają się do upowszechniania wiedzy nabytej w procesie kształcenia, lecz także rozwijają ją, wzbogacając o efekty działania kręgów - wzajemne uczenie się od siebie ${ }^{57}$.

Rozwój form uczenia się od siebie w singapurskim systemie doskonalenia nauczycieli widoczny jest również $\mathrm{w}$ tak zwanych profesjonalnych społecznościach uczenia się/uczących się (Professional Learning Communities PLC). PLC to, według definicji Narodowego Instytutu Edukacji, społeczności

\footnotetext{
${ }^{56}$ D.A. Schön, The reflective practitioner. How professionals think in action, New York 1983.

${ }_{57}$ T.L. Choo, L. Darling-Hammond, Creating Effective Teachers and Leaders, s. 37.
} 
praktyków, którzy uczestniczą w ustawicznym procesie zdobywania nowej lub rozwijania już posiadanej wiedzy oraz nabywania nowych umiejętności i kompetencji społecznych poprzez działania grupowe, uwzględniające, między innymi, wspólne analizowanie różnorodnych sytuacji edukacyjnych lub rozwiązywanie charakterystycznych dla środowiska szkolnego problemów ${ }^{58}$. Jest to przykład procesu znanego pod nazwą peer to peer learning - procedury dzielenia się doświadczeniami i dobrymi praktykami. Celem tworzenia w poszczególnych szkołach tej specyficznej platformy umożliwiającej stałą wymianę poglądów, pomysłów i opinii jest stworzenie warunków niezbędnych do efektywnego współdziałania, którego kluczowym i zarazem finalnym efektem ma być, obok wzrostu kompetencji samych nauczycieli, pozytywny wpływ na powierzonych im uczniów (nie tylko w sferze osiągnięć szkolnych, ale również w zakresie aktywności wykraczających poza mury danej placówki). Nie ulega wątpliwości, że umiejętne zorganizowanie i zarządzanie PLC może prowadzić do międzypokoleniowego transferu wiedzy, umiejętności i kompetencji. Zarówno początkujący, jak i starsi stażem nauczyciele mogą wzajemnie dzielić się swoimi umiejętnościami czy doświadczeniem - na przykład młodsi mogą pomagać starszym koleżankom i kolegom w efektywnym opanowywaniu nowych technologii, natomiast starsi mogą przekazywać im w zamian swoje zgromadzone, na przestrzeni lat, bezcenne doświadczenie zawodowe.

Obecnie instytucją odpowiedzialną za tworzenie społeczności praktyków w singapurskich placówkach oświaty jest Akademia Singapurskich Nauczycieli (Academy of Singapore Teachers - AST) - organizacja, która została utworzona przez ministerstwo w 2010 roku $^{59}$, a której rolą jest stanowienie siły przewodniej postępu i zawodowego rozwoju singapurskich pedagogów.

\section{Ewaluacja pracy nauczyciela - w stronę mistrzostwa}

Precyzyjnie w szczegółach zaplanowany system dokształcania i doskonalenia nauczycieli jest w modelu singapurskim uzupełniany przez niezwykle rygorystyczny i skrupulatnie wykorzystywany program oceny pracowniczej. Singapurscy nauczyciele poddawani są rokrocznie ocenie przeprowadzanej przez specjalnie $\mathrm{w}$ tym celu powoływane zespoły ekspertów, których zadaniem jest ewaluacja czynnych zawodowo pedagogów w zakresie szesnastu kompetencji rdzeniowych z perspektywy efektywnej pracy szkolnej. Pod uwagę brane są, między innymi, osiągnięcia w następujących obszarach:

${ }_{58}$ D. Lee, W.Y. Tay, H. Hong, Professional learning communities: A movement for teacher-led professionalism, NIE Working Paper Series, No. 6, Singapore 2015, s. 6.

59 OECD, Lessons from PISA for the United States, s. 169. 
wkład nauczyciela w proces rozwoju potencjału jego uczniów (nie tylko w sferze osiągnięć szkolnych, lecz także w zakresie rozwoju ich właściwości wewnętrznych, jak np. osobowość), poziom współpracy z rodzicami uczniów oraz z organizacjami społeczności lokalnej, czy wkład wniesiony w pracę innych nauczycieli oraz szkoły, z perspektywy instytucjonalnej, traktowanej jako całość. Nie można pominąć w analizowanym kontekście faktu, że do stałego podnoszenia efektów własnej pracy, wyrażającego się przede wszystkim w wysokich, ponad przeciętnych w skali Singapuru osiągnięciach, nauczycieli motywuje nie tylko ich własna ambicja i wewnętrzna potrzeba samodoskonalenia, lecz także perspektywa otrzymania znacznej premii finansowej (każda szkoła dysponuje specjalną pulą pieniędzy przeznaczonych właśnie na tego rodzaju dodatkowe wynagrodzenia dla wyróżniających się nauczycieli ${ }^{60}$. Po upływie trzech lat od chwili podjęcia pierwszej pracy (po ukończeniu NIE), młodzi nauczyciele poddawani są ewaluacji mającej określić, która z trzech dostępnych dla singapurskich nauczycieli ścieżek rozwoju zawodowego najpełniej odpowiada ich kompetencjom:

- ścieżka przywódcza (Leadership Track) - prowadzi do kariery w administracji szkolnej (w jej obrębie dochodzi do selekcji przyszłych dyrektorów szkół);

- ścieżka specjalistyczna (Senior Specialist Track) - prowadzi do kariery w obszarze projektowania programów nauczania, psychologii szkolnej i doradztwa zawodowego, statystyki, testów i pomiarów, czy różnego rodzaju badań edukacyjnych;

- ścieżka nauczycielska (Teaching Track) - prowadzi do kariery skoncentrowanej na osiągnięcie mistrzostwa w zawodzie nauczyciela ${ }^{61}$.

Identyfikowane $\mathrm{w}$ procesie permanentnej oceny predyspozycje poszczególnych nauczycieli są kolejnym aspektem singapurskiego systemu, który zorientowany jest na pełne wykorzystanie potencjału osobowego zarówno z punktu widzenia rozwoju osobistego, jak i z szerszej perspektywy optymalnego wkładu przedstawicieli nauczycielskiej profesji w niekończący się proces budowania osiągnięć społeczeństwa Singapuru. Przyporządkowanie nauczycieli do potencjalnych ścieżek rozwoju dobieranych pod kątem ich predyspozycji jest dobitnym dowodem na to, że system singapurski nie zostawia niczego przypadkowi i w kreowanych rozwiązaniach kieruje się niezachwianą racjonalnością oraz logiką. Wyraźnego podkreślenia wymaga przy tym fakt, że kryteria uzyskiwania kolejnych poziomów w ramach wyróżnionych ścieżek zawodowego rozwoju powiązane są ściśle z nabywaniem i rozwijaniem konkretnych kompetencji, co sprawia, że zarówno dla samego nauczy-

${ }^{60}$ Tamże, s. 170.

${ }^{61}$ L. Steiner, Using Competency-Based Evaluation to Drive Teacher Excellence. Lessons from Singapore, Chapel Hill 2010, s. 16. 
ciela, jak i dla osób odpowiedzialnych za nadzór nad jego pracą i czynionymi przez niego postępami, zakres działań niezbędnych w procesie starania się o zawodowy awans sformułowany jest w sposób w pełni zrozumiały ${ }^{62}$.

Singapurski system oceny pracowniczej obejmuje także sporządzanie przez nauczycieli, na początku każdego roku szkolnego, listy celów, które zamierzają oni w jego trakcie zrealizować. Na tym etapie nauczyciele mogą być wspomagani wskazówkami dyrektora szkoły, który służy im radą i pomocą $\mathrm{w}$ procesie identyfikacji kluczowych obszarów ich dalszego rozwoju. Co równie istotne, wspomniana lista tworzona jest, między innymi, na podstawie przytoczonej powyżej corocznej oceny pracownika - nauczyciel, po zapoznaniu się z nią, ma za zadanie określić sfery, którym powinien poświęcić więcej uwagi, by optymalnie doskonalić warsztat pracy. Planowane na dany rok szkolny zamierzenia nauczyciel umiejscawia w czterech zasadniczych obszarach:

- wszechstronny rozwój uczniów poprzez osiągnięcie wysokiej jakości i efektywności procesu nauczania, prowadzenie zajęć pozalekcyjnych oraz zapewnienie warunków niezbędnych dla efektywnej nauki;

- wkład wnoszony w działalność i rozwój szkoły;

- współpraca z rodzicami;

- rozwój zawodowy (np. identyfikacja typu szkoleń, w jakich nauczyciel powinien wziąć udział, by wzmocnić swe słabe strony uwzględnione w ocenie rocznej) ${ }^{63}$.

Można przyjąć, iż tak ukierunkowany system corocznej ewaluacji w istotny sposób przyczynia się do osiągania przez singapurskich nauczycieli mistrzostwa w zawodzie, przekładającego się na wysokie osiągnięcia szkolne ich uczniów.

\section{Podsumowanie}

Utopia wyłania się z negacji jakiegoś status quo, którego zasadność, sprawiedliwość, czy też inne cechy są krytykowane. Jednak przyjęcie wyłącznie tego kryterium wyłaniającego model utopijny byłoby mało precyzyjne. W rozważaniach o utopii istotne jest zwrócenie uwagi na podstawową kwestię. Utopia nie jest reformą, lecz projektem gruntownej przebudowy stosunków społeczno-gospodarczych, a jej cechę konstytutywną stanowi "przekroczenie obecnej rzeczywistości i dojście do pewnego ideału” - do „stanu ostatecznego i nieprzekraczalnego", w którym nie można już nic więcej po-

\footnotetext{
62 Tamże, s. 15.

63 Tamże, s. 13-14.
} 
prawić ${ }^{64}$. W utopii przyjmuje się istnienie formy doskonałej, co buduje sztywność i homogeniczność wizji, prowadząc tym samym do wielu nieuzasadnionych uproszczeń. $W$ tej perspektywie system kształcenia i doskonalenia nauczycieli w Singapurze bez wątpienia nie jest utopią, lecz sprawnie zaprojektowanym spójnym układem precyzyjnie ze sobą powiązanych elementów, które stanowią system otwarty na zmiany i doskonalenie ${ }^{65}$. Jednak i tu może pojawić się wątpliwość, bowiem już samo założenie o możliwości stworzenia w sposób konstruktywistyczny idealnego systemu F. von Hayek uważa za „zgubną pychę rozumu", czyli wiarę o charakterze utopijnym ${ }^{66}$.

Rzeczywistość Singapuru ukazuje zintegrowany, sprawnie działający mechanizm, w którym decyzje ekonomiczne są motywowane racjonalną oceną sytuacji wyjściowej i celu do osiągnięcia. Diagnoza ta przywołuje z kolei ujęcie neoliberałów, w którym to rynek jest interpretowany jako „mechanizm maksymalnie efektywny i niezawodny, którego zdolność do regulacji i racjonalności traktowana jest niemal dogmatyczna, a wahania koniunktury i kryzysy przypisywane są (nieracjonalnej) działalności państwa" ${ }^{67}$. Upraszczając, rynek poprzez duże zyski w naturalny sposób nagradza efektywność, zaś karze nieefektywnych, eliminując ich z gry. I przyjęcie takiego założenia ma niewątpliwie charakter utopijny. Kreacje utopistyczne prowadzą do uszczęśliwienia ludzi poprzez zaspokojenie wszelkich potrzeb materialnych. W tym procesie mechanizmem samoregulującym jest wolny rynek.

Precyzja założeń i realizacji zorientowanych na wysoką jakość oraz efektywność singapurskiego systemu kształcenia i doskonalenia nauczycieli ukazuje pewne związki; cechy wspólne z modelem utopijnym. Jeśli jednak istotą utopii jest transcendencja, bowiem „każda utopia jest oscylowaniem, w zawieszeniu, pomiędzy tym, co możliwe i tym, co niemożliwe" ${ }^{\prime 68}$, to rozwiązania singapurskie, choć bez wątpienia modelowe, nie są utopią. Singapur wypracował wysoce pragmatyczny system łączenia nowych zdobyczy nauki z ograniczeniami rodzimego kontekstu uwarunkowań - jego mocnych, jak i słabych stron. W efekcie nie doświadcza problemów z odejściem nauczycieli z pracy, z nieskutecznymi nauczycielami, czy uciążliwym kierownictwem, które stanowią plagę wielu innych systemów edukacyjnych na świecie. Wydaje się,

${ }^{64}$ L. Kołakowski, Moje stuszne poglądy na wszystko, Kraków 1999, s. 11-22.

${ }^{65}$ I. Nowosad, Polityka edukacyjna Singapuru. Orientacja na jakość i efektywność, [w:] Polityka oświatowa w perspektywie porównawczej, red. R. Nowakowska-Siuta, K. Dmitruk-Sierocińska, Kraków 2018 (w druku).

${ }^{66}$ F. von Hayek, za: M. Bałtowski, G. Kwiatkowski, Utopie społeczno-gospodarcze - historia i wspótczesność, Annales Universitatis Mariae Curie-Skłodowska Lublin-Polonia, 2009, XLIII, 1, s. 50 .

${ }^{67}$ M. Bałtowski, G. Kwiatkowski, tamże, s. 52.

${ }^{68}$ P. Tillich, Critique and Justification of Utopia, [w:] Utopias and Utopian Thought, red. F.E. Manuel, London 1973, s. 302, za: A. Dróżdż, Mity i utopie pedagogiczne, s. 49. 
że w tym zakresie zostawiono niewiele miejsca przypadkowi i szczęśliwym zbiegom okoliczności. Wszystkie elementy, które odgrywają lub mogą odgrywać rolę w procesie stałego podnoszenia jakości systemu edukacji zostały objęte nadzorem i kontrolą, przy jednoczesnym zapewnieniu nauczycielom pomocy i wsparcia. Tym samym, środki wydawane są celowo i trafiają wyłącznie tam, gdzie są niezbędne i zostaną efektywnie oraz produktywnie spożytkowane. Czy to utopia?

Organizacja singapurskiego systemu kształcenia i doskonalenia zawodowego nauczycieli nie pozostawia żadnych złudzeń - jest to system kompletny, efektywny, pozbawiony widocznych luk i jednocześnie otwarty na dalsze udoskonalenia. Wydaje się, że zawarto w nim wszystkie kluczowe obszary, z punktu widzenia szeroko pojmowanej nauczycielskiej powinności sprawczej zorientowanej na wysoką jakość inicjowanych procesów, przy pełnej świadomości możliwych konsekwencji - zarówno dla samych nauczycieli, jak i uczniów, szkoły oraz całego systemu edukacji. Można również przyjąć, że wykorzystano wielość narzędzi, programów i form, poprzez które państwo dąży do zapewnienia młodym pokoleniom najlepiej przygotowanej kadry pedagogicznej, z gotowością do kształcenia ustawicznego. W efekcie, nauczanie zostało przekształcone $\mathrm{w}$ konkurencyjną oraz szanowaną profesję i nie bez powodu bycie nauczycielem uznawane jest w Singapurze za zaszczyt.

\section{BIBLIOGRAFIA}

Bałtowski M., Kwiatkowski G., Utopie społeczno-gospodarcze - historia i wspótczesność, Annales Universitatis Mariae Curie-Skłodowska Lublin-Polonia, 2009, XLIII, 1.

Choo T.L., Darling-Hammond L., Creating Effective Teachers and Leaders in Singapore, [w:] Teacher and Leader Effectiveness in High-Performing Education Systems, red. L. Darling-Hammond, R. Rothman, Alliance for Excellent Education and Stanford, CA: Stanford Center for Opportunity Policy in Education, Washington, DC and Stanford, California 2011.

Day Ch., Rozwój zawodowy nauczyciela. Uczenie się przez całe życie, Gdańskie Wydawnictwo Psychologiczne, Gdańsk 2004.

Drożdż A., Mity i utopie pedagogiczne, Wydawnictwo Naukowe Akademii Pedagogicznej, Kraków 2000.

Eryilmaz A., Kara A., Comparison of Teachers and Pre-Service Teachers With Respect to Personality Traits and Career Adaptability, International Journal of Instruction, 2017, 10, 1.

Gałażewski M., Atopia w teorii systemów autopojetycznych, [w:] Utopia a edukacja, red. J. Gromisz, R. Włodarczyk, t. 1 - O wyobrażeniach świata możliwego, Instytut Pedagogiki Uniwersytetu Wrocławskiego, Wrocław 2016.

IBE, Program Międzynarodowej Oceny Umiejętności Uczniów. Wyniki Badania 2015 w Polsce, Instytut Badań Edukacyjnych, Warszawa 2016.

Karpati A., Teacher training and professional development, [w:] Green Book. For the renewal of public education in Hungary, red. K. Fazekas, J. Köllô, J. Varga, ECOSTAT, Budapest 2009. 
Kołakowski L., Moje stuszne poglądy na wszystko, Wydawnictwo Znak, Kraków1999.

Kwiatkowski S.T., Osobowość studentów pedagogiki w świetle Pięcioczynnikowego Modelu Osobowości, Ruch Pedagogiczny, 2014, 1.

Lee D., Tay W.Y., Hong H., Professional learning communities: A movement for teacher-led professionalism, NIE Working Paper Series, No. 6, National Institute of Education, Singapore 2015.

Lim K.M., Teacher Education in Singapore, 2013 http:/ /www.academia.edu/23996078/Teacher_Education_and_Teaching_Profession_in_Singapor [e - dostęp: 25.09.2017].

Low E.-L., Tan O.-S., Teacher Education Policy: Recruitment, Preparation and Progression, [w:] Teacher Education in the 21st Century. Singapore's Evolution and Innovation, red. O.-S. Tan, W.-C. Liu, E.-L. Low, Springer Nature Singapore Pte, Singapore 2017.

Melosik Z., Kultura instant. Paradoksy post-tożsamości, [w:] Edukacja. Społeczne konstruowanie idei i rzeczywistości, red. M. Cylkowska-Nowak, Wydawnictwo Wolumin, Poznań 2000.

NIE, A Teacher Education Model for the $21^{\text {st }}$ Century, National Institute of Education, Singapore 2009.

Nowosad I., Perspektywy rozwoju szkoły. Szkice z teorii szkoły, Instytut Badań Edukacyjnych, Warszawa 2003.

Nowosad I., Polityka edukacyjna Singapuru. Orientacja na jakość i efektywność, [w:] Polityka oświatowa w perspektywie porównawczej, red. R. Nowakowska-Siuta, K. Dmitruk-Sierocińska, Oficyna Wydawnicza Impuls, Kraków 2018 (w druku).

OECD, Lessons from PISA for the United States, Strong Performers and Successful Reformers in Education, OECD Publishing, Paris 2011.

OECD, PISA 2012 Results in Focus. What 15-year-olds know and what they can do with what they know, OECD Publishing, Paris 2014a.

OECD, Talis 2013 Results: An International Perspective on Teaching and Learning, OECD Publishing, Paris 2014b.

OECD, Singapore - Country Note - Results for TALIS 2013, OECD Publishing, Paris 2014c.

Quacquarelli Symonds, QS World University Rankings by Subject 2017, QS, London 2017.

Schön D.A., The reflective practitioner. How professionals think in action, Basic Books, New York 1983.

Steiner L., Using Competency-Based Evaluation to Drive Teacher Excellence. Lessons from Singapore, Public Impact, Chapel Hill 2010.

Szacki J., Spotkania z utopia, Wydawnictwo Sic! Warszawa 2000.

Tan S.K.S., Wong A.F.L., Gopinathan K.C.G., Wong I.Y.F., Ong K.H., The Qualifications of the Teaching Force: Data From Singapore, [w:] A Comparative Study of Teacher Preparation and Qualifications in Six Nations, red. R.M. Ingersoll, Consortium for Policy Research in Education, Philadelphia 2007.

Tillich P., Critique and Justification of Utopia, [w:] Utopias and Utopian Thought, red. F.E. Manuel, Souvenir Press, London 1973.

UNESCO International Bureau of Education, World Data on Education - Singapore, International Buerau of Education, Geneva 2011.

Walczak D., Początkujący nauczyciele. Raport z badania jakościowego, Instytut Badań Edukacyjnych, Warszawa 2012.

Włodarczyk R., Utopia w perspektywie pedagogiki wspótczesnej, [w:] Utopia a edukacja, red. J. Gromisz, R. Włodarczyk, t. 1 - O wyobrażeniach świata możliwego, Instytut Pedagogiki Uniwersytetu Wrocławskiego, Wrocław 2016.

World Economic Forum, The Global Competitiveness Report 2014-2015: Country/Economy Highlights, New York 2014. 
